\title{
Non Destructive Application of Radioactive Tracer Isotopes for Performance Evaluation of Industrial Grade Anion Exchange Resins Tulsion A-33 and Indion NSSR
}

\author{
P. U. Singare \\ Department of Chemistry, Bhavan's College, Munshi Nagar, Andheri (West), Mumbai 400058 , India \\ Tel No. + 9122 26256451/ 52; Fax No. + 912226256453 \\ *E-mail address: pravinsingare@gmail.com
}

\begin{abstract}
The present study deals with non-destructive application of radioactive tracer isotopes to evaluate the performance of Tulsion A-33 (nuclear grade) and Indion NSSR (non-nuclear grade) anion exchange resins. The performance evaluation was done by carrying out the iodide and bromide ion-isotopic exchange reactions using the above resins. It was observed that at a constant temperature of $40.0{ }^{\circ} \mathrm{C}$, as the concentration of labeled iodide ion solution increases $0.001 \mathrm{M}$ to $0.004 \mathrm{M}$, the percentage of iodide ions exchanged increases from $58.0 \%$ to $64.0 \%$ for Tulsion A-33 resins; and from $48.4 \%$ to $50.8 \%$ for Indion NSSR resins. Similarly in case of bromide ion-isotopic exchange reaction under identical experimental conditions, the percentage of bromide ions exchanged increases from $45.6 \%$ to $50.4 \%$ for Tulsion A-33 resin; and from $39.8 \%$ to $44.6 \%$ for Indion NSSR resin. It was also observed that during iodide ion-isotopic exchange reaction at $40.0{ }^{\circ} \mathrm{C}$, using $1.000 \mathrm{~g}$ of ion exchange resins and $0.003 \mathrm{M}$ labeled ionic solution, using Tulsion A-33 resin the values of specific reaction rate $\left(\mathrm{min}^{-1}\right)$, amount of iodide ion exchanged $(\mathrm{mmol})$, initial rate of iodide ion exchange $(\mathrm{mmol} / \mathrm{min})$ and $\log \mathrm{K}_{\mathrm{d}}$ were $0.229,0.469,0.107$ and 10.6 respectively, which was higher than the values of $0.167,0.375,0.063$ and 7.6 respectively as obtained by using Indion NSSR resins under identical experimental conditions. The overall results indicate superior performance of Tulsion A-33 over Indion NSSR resin under identical operational parameters.
\end{abstract}

Keywords: radioisotopes; non-destructive technique; Tulsion A-33; Indion NSSR; nuclear grade resin; anion exchange resins; performance evaluation; operational parameters; ${ }^{131} \mathrm{I} ;{ }^{82} \mathrm{Br}$

\section{INTRODUCTION}

The availability of a wide spectrum of radioisotopes from the reactors and cyclotrons led to the quest for their beneficial applications in diverse fields such as medicine, industry and agriculture. Though radioisotopes have been applied to the solution of problems in industry for over 50 years, research and development of the technology continues unabated. Because of their unique properties, radioactive isotopes can be used to obtain information about plants and processes that cannot be obtained in any other way. It is possible to apply the radiotracers in order to investigate the efficiency of several devices in a wastewater treatment plant (primary and secondary clarifiers, aeration tank) [1]. Often, the information is 
obtained with the plant on-stream and without disrupting the process in any way. By monitoring the radioactivity both continuously or after sampling (depending on the nature of study), the movement, adsorption, retention etc. of the tracer and in turn, of the bulk matter under investigation, can be followed. This can lead to substantial economic benefits, from shutdown avoidance to process optimization. Application of radioisotopes in certain manufacturing processes to induce desired chemical reactions is also reported in the literature [2]. As a result radioisotopes have become useful tool in various industrial applications [2]. Unlike many other advanced technologies, isotope applications have a very low gestation period. A technology developed in the laboratory is often successfully applied in the field within a very short time span.

This make isotope technology one of the highly visible peaceful uses of nuclear energy and a major reason for continuing with nuclear research. Radiotracer methodology is described extensively in the literature [3-5]. Generally in most of these applications the radioisotopes preferred are gamma emitters having half-life compatible with the duration of studies; also the strength of radioactivity used varies depending on the nature of application. Considering the widespread non-destructive application of radioactive isotopes, in the present investigation attempts are made to apply them for performance evaluation of industrial grade ion exchange resins Tulsion A-33 and Indion NSSR under different experimental conditions.

\section{EXPERIMENTAL}

\section{1. Conditioning of ion exchange resins}

Tulsion A-33 a nuclear grade resin in hydroxide form (by Thermax India Ltd., Pune, India), and Indion NSSR a non-nuclear grade resin in chloride form (by Ion Exchange India Ltd., Mumbai, India) are strongly basic anion exchange resin having quaternary ammonium $\mathrm{N}^{+}\left(\mathrm{CH}_{3}\right)_{3}$ functional group. Details regarding the properties of the resins used are given in Table 1 . These resins were converted separately in to iodide / bromide form by treatment with $10 \% \mathrm{KI} / \mathrm{KBr}$ solution in a conditioning column which is adjusted at the flow rate as $1 \mathrm{~mL} /$ min. The resins were then washed with double distilled water, until the washings were free from iodide/bromide ions as tested by $\mathrm{AgNO}_{3}$ solution. These resins in bromide and iodide form were then dried separately over $\mathrm{P}_{2} \mathrm{O}_{5}$ in desiccators at room temperature.

Table 1. Properties of ion exchange resins.

\begin{tabular}{|c|c|c|c|c|c|c|}
\hline $\begin{array}{c}\text { Ion } \\
\text { exchange } \\
\text { resin }\end{array}$ & Matrix & $\begin{array}{c}\text { Particle } \\
\text { Size } \\
(\mathrm{mm})\end{array}$ & $\begin{array}{c}\text { Moisture } \\
\text { content } \\
(\%)\end{array}$ & $\begin{array}{c}\text { Operating } \\
\mathrm{pH}\end{array}$ & $\begin{array}{c}\text { Maximum } \\
\text { operating } \\
\text { temperature } \\
\left({ }^{\circ} \mathrm{C}\right)\end{array}$ & $\begin{array}{c}\text { Total } \\
\text { exchange } \\
\text { capacity } \\
(\mathrm{meq} . / \mathrm{mL})\end{array}$ \\
\hline Tulsion A-33 & $\begin{array}{c}\text { Polystyrene } \\
\text { copolymer }\end{array}$ & $0.3-1.2$ & 60 & $0-14$ & 60 & 1.00 \\
\hline Indion NSSR & $\begin{array}{c}\text { Polystyrene } \\
\text { copolymer }\end{array}$ & $0.3-1.2$ & 50 & $0-14$ & 100 & 0.9 \\
\hline
\end{tabular}




\section{2. Radioactive Tracer Isotopes}

2.

Details regarding the isotopes used in the present experimental work are given in Table

Table 2. Properties of ${ }^{131} \mathrm{I}$ and ${ }^{82} \mathrm{Br}$ tracer isotopes [6].

\begin{tabular}{|c|c|c|c|c|c|}
\hline Isotopes & Half-life & $\begin{array}{c}\text { Radioactivity } \\
/ \mathrm{mCi}\end{array}$ & $\begin{array}{c}\gamma \text { - energy } \\
/ \mathrm{MeV}\end{array}$ & $\begin{array}{c}\text { Chemical } \\
\text { form }\end{array}$ & $\begin{array}{c}\text { Physical } \\
\text { form }\end{array}$ \\
\hline $131 \mathrm{I}$ & $8.04 \mathrm{~d}$ & 5 & 0.36 & Iodide* & Aqueous \\
\hline $82 \mathrm{Br}$ & $36 \mathrm{~h}$ & 5 & 0.55 & Bromide** & Aqueous \\
\hline
\end{tabular}

* Sodium iodide in dilute sodium sulphite.

** Ammonium bromide in dilute ammonium hydroxide.

\section{3. Study on kinetics of iodide ion-isotopic exchange reaction}

In a stoppered bottle $250 \mathrm{~mL}(\mathrm{~V})$ of $0.001 \mathrm{M}$ iodide ion solution was labeled with diluted ${ }^{131} \mathrm{I}$ radioactive solution using a micro syringe, such that $1.0 \mathrm{~mL}$ of labeled solution has a radioactivity of around 15,000 cpm (counts per minute) when measured with $\gamma$-ray spectrometer having NaI (Tl) scintillation detector. Since only about 50-100 $\mu \mathrm{L}$ of the radioactive iodide ion solution was required for labeling the solution, its concentration will remain unchanged, which was further confirmed by potentiometer titration against $\mathrm{AgNO}_{3}$ solution.

The above labeled solution of known initial activity $\left(A_{i}\right)$ was kept in a thermostat adjusted to $30.0{ }^{\circ} \mathrm{C}$. The swelled and conditioned dry ion exchange resins in iodide form weighing exactly $1.000 \mathrm{~g}(\mathrm{~m})$ were transferred quickly into this labeled solution which was vigorously stirred by using mechanical stirrer and the activity in cpm of $1.0 \mathrm{~mL}$ of solution was measured. The solution was transferred back to the same bottle containing labeled solution after measuring activity. The iodide ion-isotopic exchange reaction can be represented as:

$$
\mathrm{R}-\mathrm{I}+\mathrm{I}^{*-}{ }_{(\text {aq. })} \rightleftharpoons \mathrm{R}-\mathrm{I}^{*}+\mathrm{I}^{-}{ }_{\text {(aq.) }}
$$

here R-I represents ion exchange resin in iodide form; $\mathrm{I}^{{ }^{-}}{ }_{\text {(aq.) }}$ represents aqueous iodide ion solution labeled with ${ }^{131}$ I radiotracer isotope [17-19].

The activity of solution was measured at a fixed interval of every $2.0 \mathrm{~min}$. The final activity $\left(A_{f}\right)$ of the solution was also measured after $3 \mathrm{~h}$ which was sufficient time to attain the equilibrium [7-12]. The activity measured at various time intervals was corrected for background counts.

Similar experiments were carried out by equilibrating separately $1.000 \mathrm{~g}$ of ion exchange resin in iodide form with labeled iodide ion solution of four different concentrations ranging up to $0.004 \mathrm{M}$ at a constant temperature of $30.0{ }^{\circ} \mathrm{C}$. The experimental sets were also repeated for higher temperatures up to $45.0^{\circ} \mathrm{C}$. 


\section{4. Study on kinetics of bromide ion-isotopic exchange reaction}

The experiment was also performed to study the kinetics of bromide ion- isotopic exchange reaction by equilibrating $1.000 \mathrm{~g}$ of ion exchange resin in bromide form with labeled bromide ion solution in the same concentration and temperature range as above. The labeling of bromide ion solution was done by using ${ }^{82} \mathrm{Br}$ as a radioactive tracer isotope for which the same procedure as explained above was followed. The bromide ion-isotopic exchange reaction can be represented as:

$$
\mathrm{R}-\mathrm{Br}+\mathrm{Br}^{*-}{ }_{(\text {aq. })} \rightleftharpoons \mathrm{R}-\mathrm{Br}^{*}+\mathrm{Br}^{-}{ }_{(\text {aq. })}
$$

here $\mathrm{R}-\mathrm{Br}$ represents ion exchange resin in bromide form; $\mathrm{Br}^{*-}{ }_{(\mathrm{aq} .)}$ represents aqueous bromide ion solution labeled with ${ }^{82} \mathrm{Br}$ radiotracer isotope [17-19].

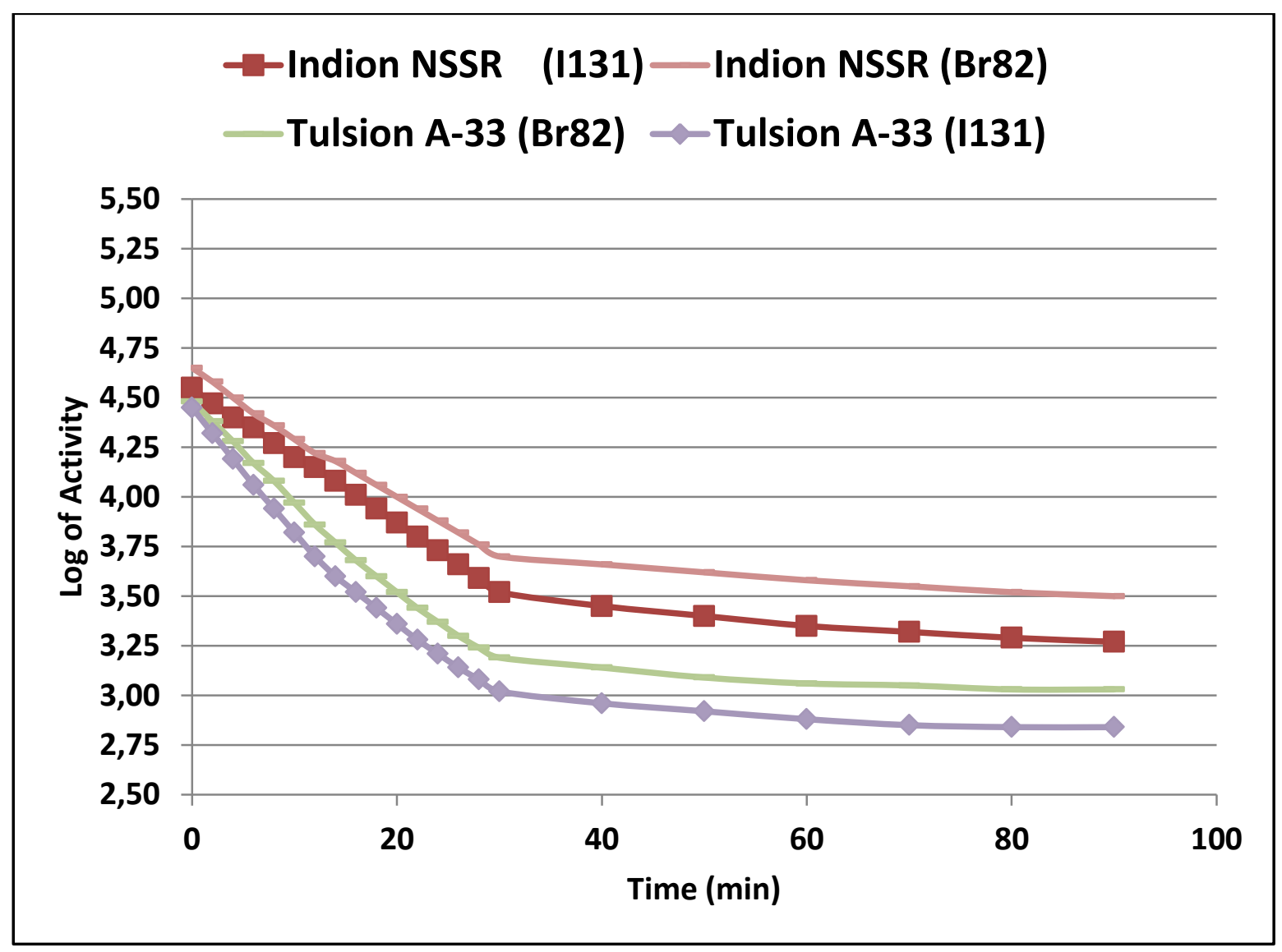

Figure 1. Kinetics of Ion-Isotopic Exchange Reactions. Amount of ion exchange resin $=1.000 \mathrm{~g}$, Concentration of labeled exchangeable ionic solution $=0.003 \mathrm{M}$, Volume of labeled ionic solution $=250 \mathrm{~mL}$, Temperature $=40.0^{\circ} \mathrm{C}$ 
Table 3. Concentration effect on Ion-Isotopic Exchange Reactions.

Amount of ion exchange resin $=1.000 \mathrm{~g}$

Volume of labeled ionic solution $=250 \mathrm{~mL}$

Temperature $=40.0^{\circ} \mathrm{C}$

\begin{tabular}{|c|c|c|c|c|c|c|}
\hline$\stackrel{\odot}{8}$ & $\stackrel{8}{8}$ & $\stackrel{8}{8}$ & $\stackrel{\circ}{8}$ & \multicolumn{3}{|c|}{$\begin{array}{c}\text { Concentration of ionic solution } \\
\text { (M) }\end{array}$} \\
\hline $\bar{\S}$ & 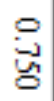 & $\stackrel{\odot}{\mathscr{S}}$ & $\stackrel{\circ}{\stackrel{0}{0}}$ & \multicolumn{3}{|c|}{$\begin{array}{l}\text { Amount of ions in } 250 \mathrm{~mL} \text { solution } \\
(\mathrm{mmol})\end{array}$} \\
\hline $\begin{array}{l}0 \\
\mathbb{8} \\
\end{array}$ & 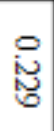 & 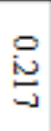 & $\stackrel{\circ}{\stackrel{0}{\circ}}$ & $\begin{array}{l}\text { Specific reaction rate of } \\
\text { rapid process } \\
\text { min }^{-1}\end{array}$ & \multirow{4}{*}{ 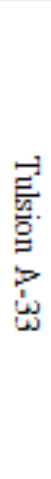 } & \multirow{8}{*}{ 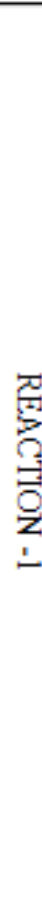 } \\
\hline $\begin{array}{l}\odot \\
8 \\
8\end{array}$ & $\begin{array}{l}8 \\
\text { B }\end{array}$ & $\stackrel{\odot}{\stackrel{\leftrightarrow}{8}}$ & E & $\begin{array}{l}\text { Amount of iodide ion } \\
\text { exchanged (mmol) }\end{array}$ & & \\
\hline$\stackrel{\odot}{\overbrace{\perp}}$ & $\stackrel{\circ}{\varrho}$ & $\stackrel{\circ}{\mathscr{\&}}$ & $\stackrel{\circ}{\mathscr{H}}$ & $\begin{array}{l}\text { Initial rate of iodide ion } \\
\text { exchange (mmol/min) }\end{array}$ & & \\
\hline E & $\Xi$ & $i_{n}$ & $\stackrel{\infty}{\infty}$ & $\log \mathrm{K}_{\delta}$ & & \\
\hline$\stackrel{0}{-1}$ & $\stackrel{\circ}{9}$ & $\stackrel{\circ}{\mathscr{\omega}}$ & $\stackrel{?}{\mathrm{E}}$ & $\begin{array}{l}\text { Specific reaction rate of } \\
\text { rapid process } \\
\text { min }^{-1}\end{array}$ & \multirow{4}{*}{ 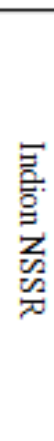 } & \\
\hline$\stackrel{\odot}{\stackrel{\circ}{\varnothing}}$ & $\bigodot_{\substack{\omega \\
\mathcal{U}}}^{0}$ & $\begin{array}{l}\stackrel{8}{\mathrm{~N}} \\
\mathrm{E}\end{array}$ & $\stackrel{\circ}{\underline{E}}$ & $\begin{array}{l}\text { Amount of iodide ion } \\
\text { exchanged } \\
\text { (mmol) }\end{array}$ & & \\
\hline$\stackrel{\circ}{8}$ & $\stackrel{\circ}{\mathscr{\leftrightarrow}}$ & $\stackrel{\circ}{\mathscr{G}}$ & $\stackrel{8}{9}$ & $\begin{array}{l}\text { Initial rate of iodide ion } \\
\text { exchanged ( } \mathrm{mmol} / \mathrm{min})\end{array}$ & & \\
\hline $\begin{array}{l}\infty \\
0\end{array}$ & $\vec{a}$ & $\overrightarrow{0}$ & on & $\log \mathrm{K}_{d}$ & & \\
\hline$\stackrel{\circ}{\infty}$ & $\stackrel{\circ}{6}$ & $\stackrel{0}{=}$ & $\stackrel{0}{0}$ & $\begin{array}{l}\text { Specific reaction rate of } \\
\text { rapid process } \\
\text { min }^{-1}\end{array}$ & \multirow{4}{*}{ 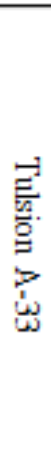 } & \multirow{8}{*}{ 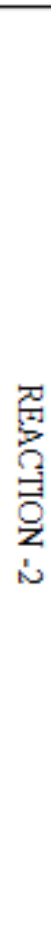 } \\
\hline $\begin{array}{l}\stackrel{\circ}{0} \\
\stackrel{8}{\Phi}\end{array}$ & 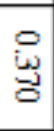 & $\begin{array}{l}\circ \\
i \\
\mathbb{E}\end{array}$ & $\stackrel{0}{1}$ & $\begin{array}{l}\text { Amount of bromide ion } \\
\text { exchanged } \\
(\mathrm{mmol})\end{array}$ & & \\
\hline$\stackrel{\circ}{8}$ & $\stackrel{\circ}{\circ}$ & $\stackrel{\circ}{\circ}$ & $\stackrel{\circ}{6}$ & $\begin{array}{l}\text { Initial rate of bromide ion } \\
\text { exchange ( } \mathrm{mmol} / \mathrm{min})\end{array}$ & & \\
\hline$\underset{\omega}{\circ}$ & $\stackrel{\infty}{\infty}$ & $\stackrel{\infty}{\circ}$ & $\overrightarrow{u_{n}}$ & $\log \mathrm{K}_{\delta}$ & & \\
\hline$\stackrel{\odot}{ \pm}$ & $\stackrel{\varrho}{\omega_{n}^{\prime}}$ & $\stackrel{\circ}{:}$ & $\stackrel{\circ}{8}$ & $\begin{array}{l}\text { Specific reaction rate of } \\
\text { rapid process } \\
\text { min }^{-1}\end{array}$ & \multirow{4}{*}{ 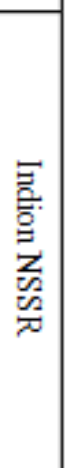 } & \\
\hline 吾 & 怘 & $\stackrel{\circ}{\stackrel{\circ}{\circ}}$ & $\stackrel{\circ}{8}$ & $\begin{array}{c}\text { Amount of bromide ion } \\
\text { exchanged } \\
\text { (mmol) }\end{array}$ & & \\
\hline$\stackrel{\circ}{\mathscr{6}}$ & $\stackrel{8}{\mathrm{C}}$ & $\stackrel{\circ}{8}$ & $\stackrel{\circ}{\mathrm{O}}$ & $\begin{array}{l}\text { Initial rate of bromide ion } \\
\text { exchange ( } \mathrm{mmol} / \mathrm{min})\end{array}$ & & \\
\hline$\infty$ & $\vec{\omega}$ & $\omega$ & w & $\log K_{d}$ & & \\
\hline
\end{tabular}


Table 4. Temperature effect on Ion-Isotopic Exchange Reactions. Amount of ion exchange resin $=1.000 \mathrm{~g}$

Concentration of labeled exchangeable ionic solution $=0.003 \mathrm{M}$

Volume of labeled ionic solution $=250 \mathrm{~mL}$

Amount of exchangeable ions in $250 \mathrm{~mL}$ labeled solution $=0.750 \mathrm{mmol}$

\begin{tabular}{|c|c|c|c|c|c|c|}
\hline 点 & $\stackrel{8}{8}$ & $\underset{b}{\omega}$ & 岁 & \multicolumn{3}{|l|}{ Temperature ${ }^{\circ} \mathrm{C}$} \\
\hline$\frac{\ddot{0}}{\infty}$ & $\stackrel{\circ}{8}$ & 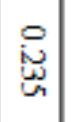 & 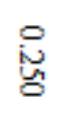 & $\begin{array}{l}\text { Specific reaction rate of } \\
\text { rapid process } \\
\text { min }^{-1}\end{array}$ & \multirow{7}{*}{\multicolumn{2}{|c|}{ 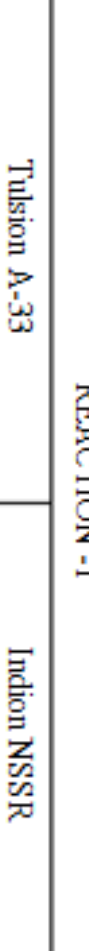 }} \\
\hline 芯 & $\begin{array}{l}\circ \\
\text { 兽 }\end{array}$ & 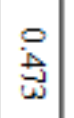 & 呑 & $\begin{array}{l}\text { Amount of iodide ion } \\
\text { exchanged } \\
\text { (mmol) }\end{array}$ & & \\
\hline 8 & $\stackrel{\circ}{9}$ & $\stackrel{\ominus}{\Xi}$ & $\stackrel{\circ}{\stackrel{0}{0}}$ & $\begin{array}{l}\text { Initial rate of iodide ion } \\
\text { exchange (mmol/min) }\end{array}$ & & \\
\hline$\subseteq$ & Б & $\Xi$ & 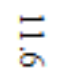 & $\log K_{s}$ & & \\
\hline 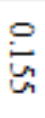 & $\stackrel{\circ}{\leftrightarrows}$ & $\stackrel{\circ}{\precsim}$ & 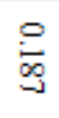 & $\begin{array}{l}\text { Specific reaction rate of } \\
\text { rapid process } \\
\text { min }^{-1}\end{array}$ & & \\
\hline 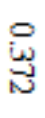 & 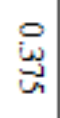 & 岕 & 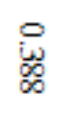 & $\begin{array}{c}\text { Amount of iodide ion } \\
\text { exchanged } \\
\text { (mmol) }\end{array}$ & & \\
\hline$\stackrel{8}{8}$ & $\stackrel{8}{8}$ & $\stackrel{8}{g}$ & $\stackrel{8}{3}$ & $\begin{array}{l}\text { Initial rate of iodide ion } \\
\text { exchange (mmol/min) }\end{array}$ & & \\
\hline 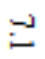 & $\vec{\alpha}$ & $\begin{array}{l}\infty \\
\omega \\
\omega\end{array}$ & $\infty$ & $\log K_{s}$ & & \\
\hline$\stackrel{\ominus}{\vec{\omega}}$ & $\stackrel{0}{-7}$ & $\stackrel{\circ}{:}$ & 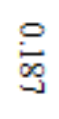 & $\begin{array}{l}\text { Specific reaction rate of } \\
\text { rapid process } \\
\text { min }^{-1}\end{array}$ & & \\
\hline$\stackrel{\ominus}{\text { 岕 }}$ & 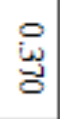 & $\stackrel{\circ}{\stackrel{\leftrightarrow}{\infty}}$ & 总 & $\begin{array}{c}\text { Amount of bromide ion } \\
\text { exchanged } \\
\text { (mmol) }\end{array}$ & $\overrightarrow{E_{2}^{2}}$ & \\
\hline 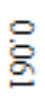 & ஜ & 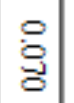 & 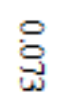 & $\begin{array}{l}\text { Initial rate of bromide ion } \\
\text { exchange (mmol/min) }\end{array}$ & 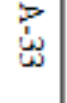 & \\
\hline$\stackrel{\infty}{-}$ & $\begin{array}{l}\infty \\
\vdots\end{array}$ & $\because$ & $\infty$ & $\log K_{\triangleleft}$ & & \\
\hline$\stackrel{0}{\breve{g}}$ & $\stackrel{\ominus}{\omega_{u}}$ & 点 & $\stackrel{\bigcirc}{\infty}$ & $\begin{array}{l}\text { Specific reaction rate of } \\
\text { rapid process } \\
\text { min }^{-1}\end{array}$ & & 覀 \\
\hline ప్ర్ & 芯 & $\stackrel{\circ}{\breve{\alpha}}$ & $\stackrel{\circ}{\stackrel{W}{S}}$ & $\begin{array}{l}\text { Amount of bromide ion } \\
\text { exchanged } \\
\text { (mmol) }\end{array}$ & $\overrightarrow{\bar{z}}$ & \\
\hline 8 & $\stackrel{8}{\mathrm{G}}$ & $\stackrel{8}{\circ}$ & 怘 & $\begin{array}{l}\text { Initial rate of bromide ion } \\
\text { exchange (mmol/min) }\end{array}$ & $\pi$ & \\
\hline$\omega$ & $\vec{\omega}$ & $\stackrel{\infty}{\infty}$ & $u_{n}$ & $\log \mathrm{K}_{6}$ & & \\
\hline
\end{tabular}




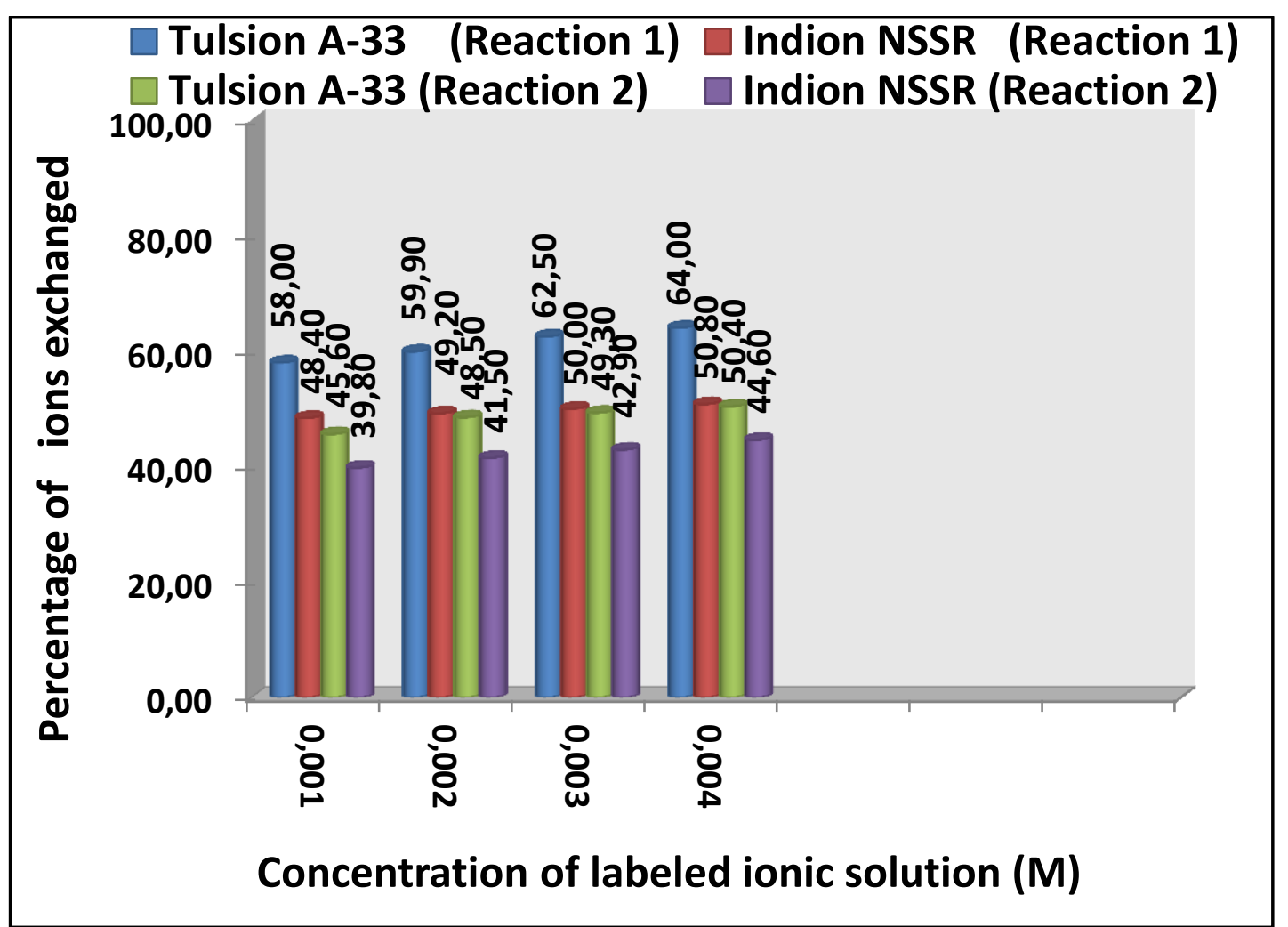

Figure 2. Variation in Percentage Ions Exchanged with Concentration of Labeled Ionic Solution. Amount of ion exchange resin $=1.000 \mathrm{~g}$, Volume of labeled ionic solution $=250 \mathrm{~mL}$, Temperature $=40.0{ }^{\circ} \mathrm{C}$.

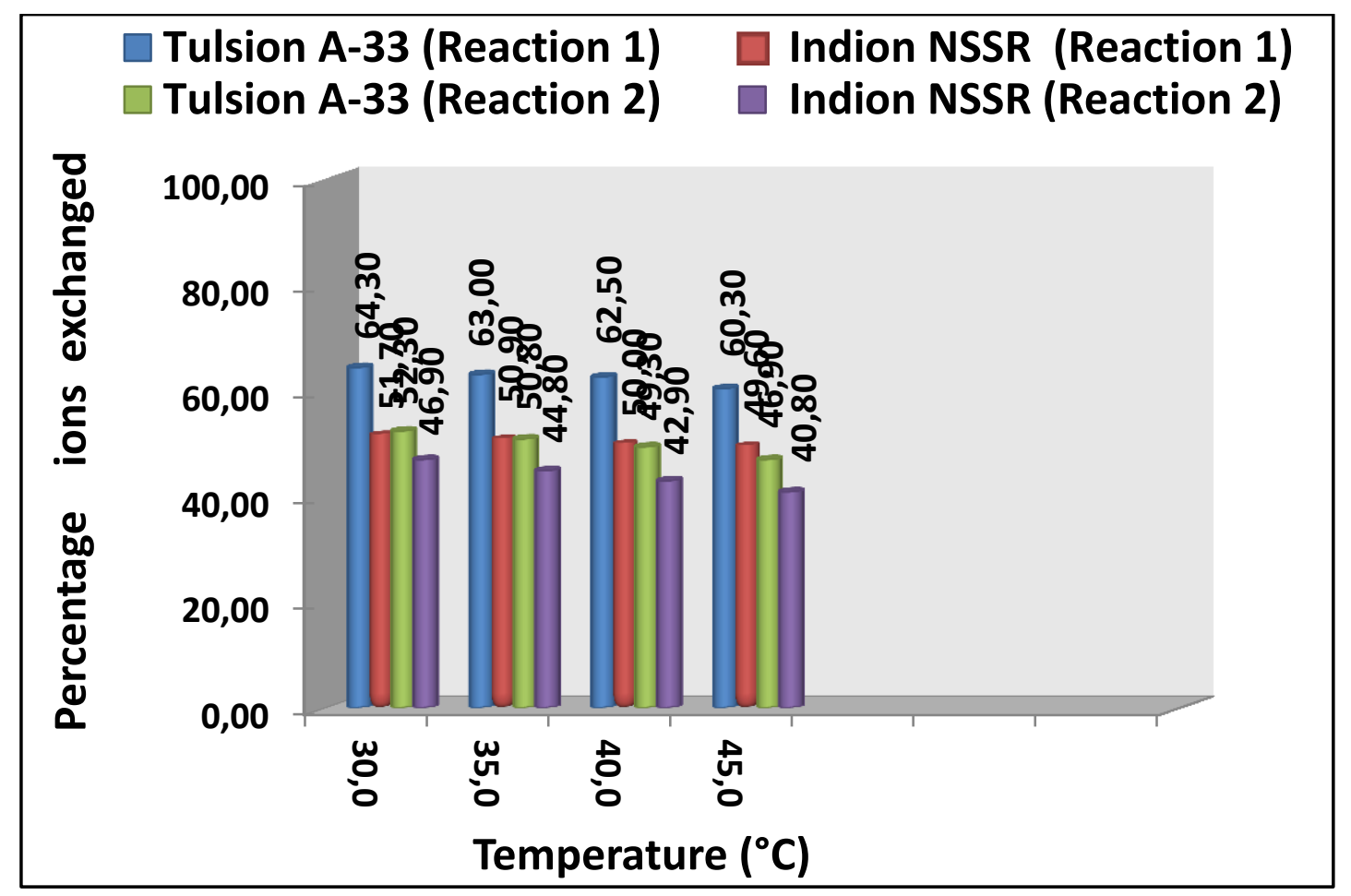

Figure 3. Variation in Percentage Ions Exchanged with Temperature of Labeled Ionic Solution. Amount of ion exchange resin $=1.000 \mathrm{~g}$, Concentration of labeled exchangeable ionic solution $=0.003 \mathrm{M}$, Volume of labeled ionic solution $=250 \mathrm{~mL}$, Amount of exchangeable ions in $250 \mathrm{~mL}$ labeled solution $=0.750$ 


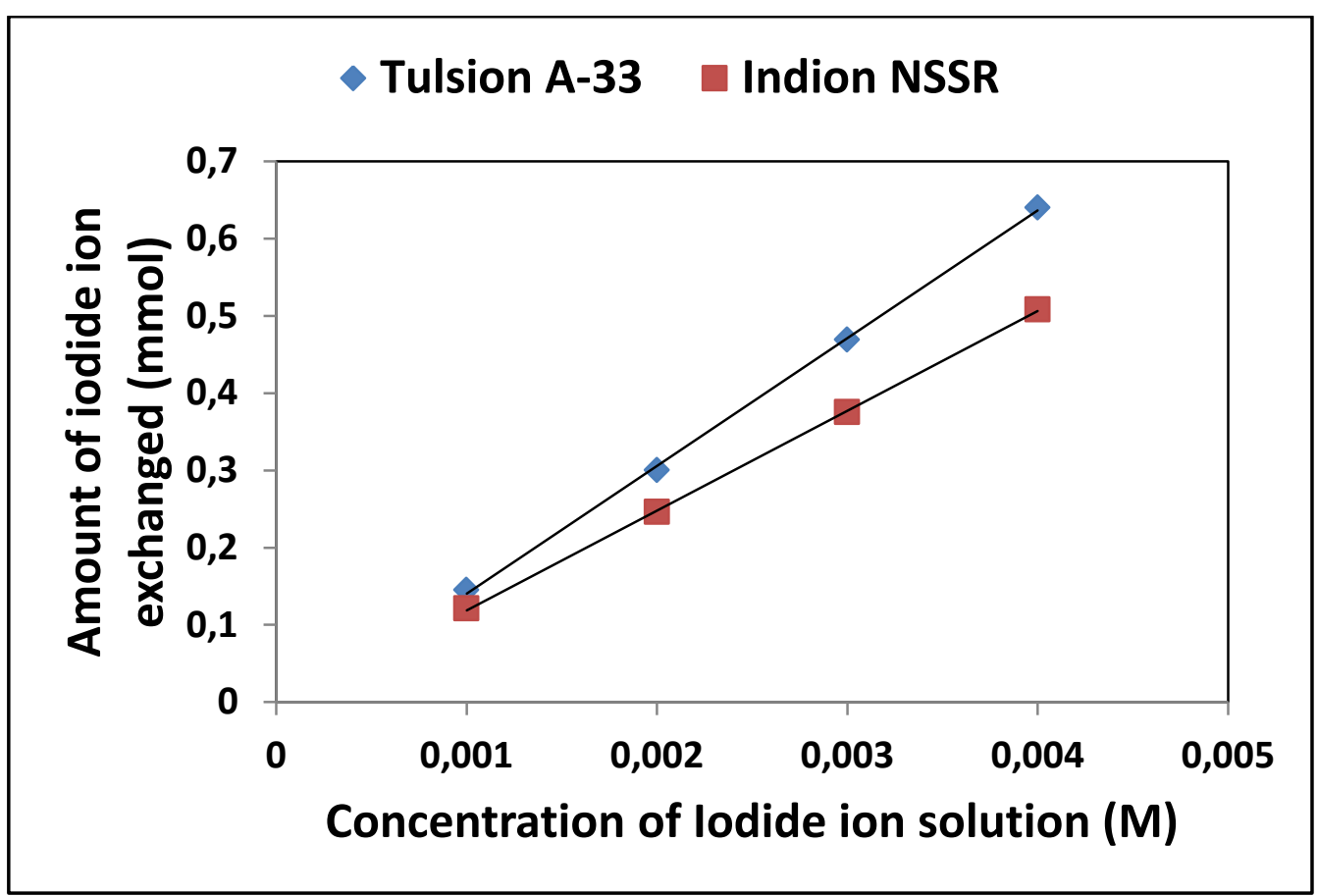

Figure 4. Correlation between concentration of iodide ion solution and amount of iodide ion exchanged.

Amount of ion exchange resin $=1.000 \mathrm{~g}$, Volume of labeled ionic solution $=250 \mathrm{~mL}$, Temperature $=40.0^{\circ} \mathrm{C}$ Correlation coefficient $(r)$ for Tulsion A-33 $=0.9997$, Correlation coefficient $(r$ ) for Indion NSSR $=0.9999$

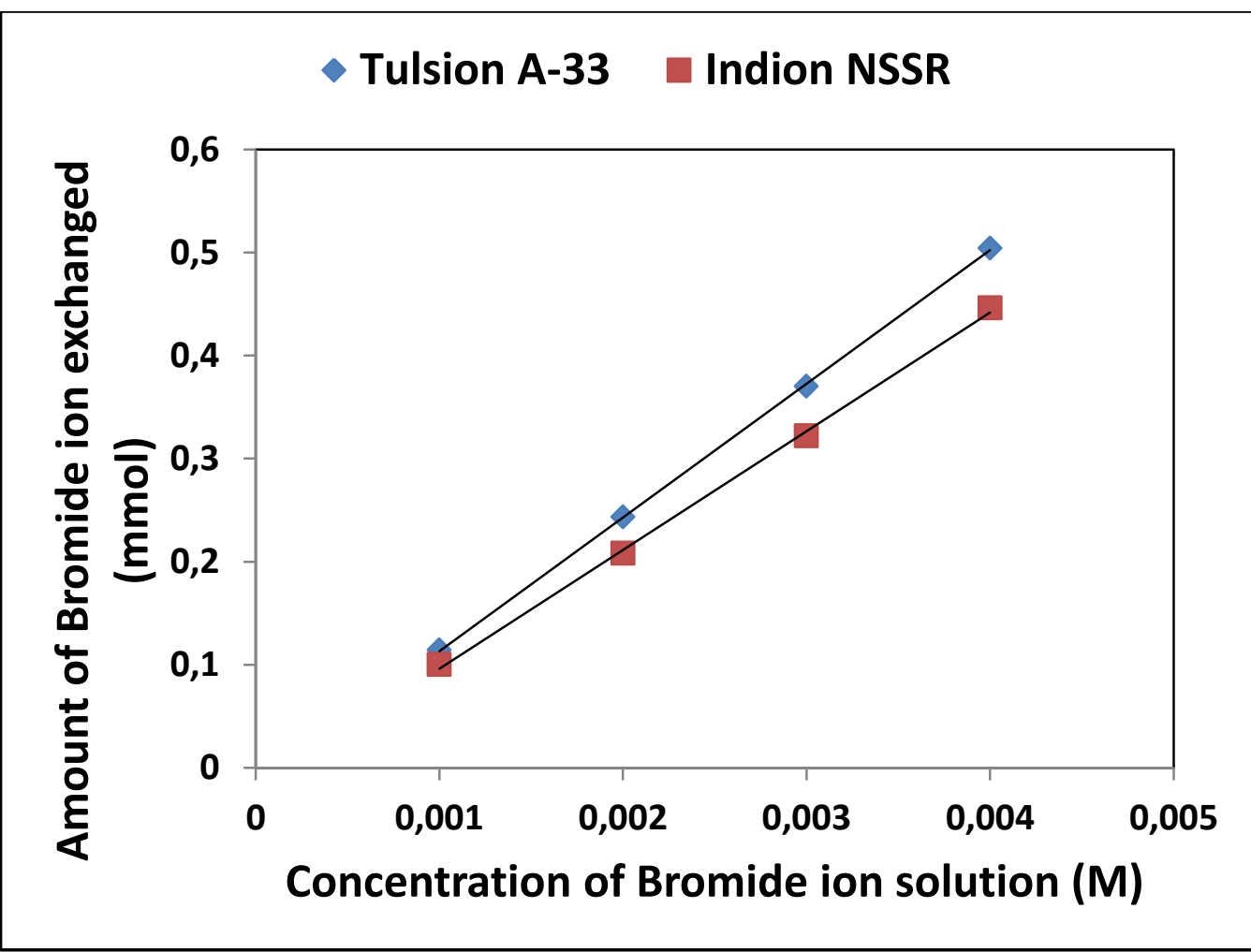

Figure 5. Correlation between concentration of bromide ion solution and amount of bromide ion exchanged.

Amount of ion exchange resin $=1.000 \mathrm{~g}$, Volume of labeled ionic solution $=250 \mathrm{~mL}$, Temperature $=40.0{ }^{\circ} \mathrm{C}$ Correlation coefficient $(r)$ for Tulsion A-33 $=0.9999$, Correlation coefficient $(r)$ for Indion NSSR $=0.9995$ 


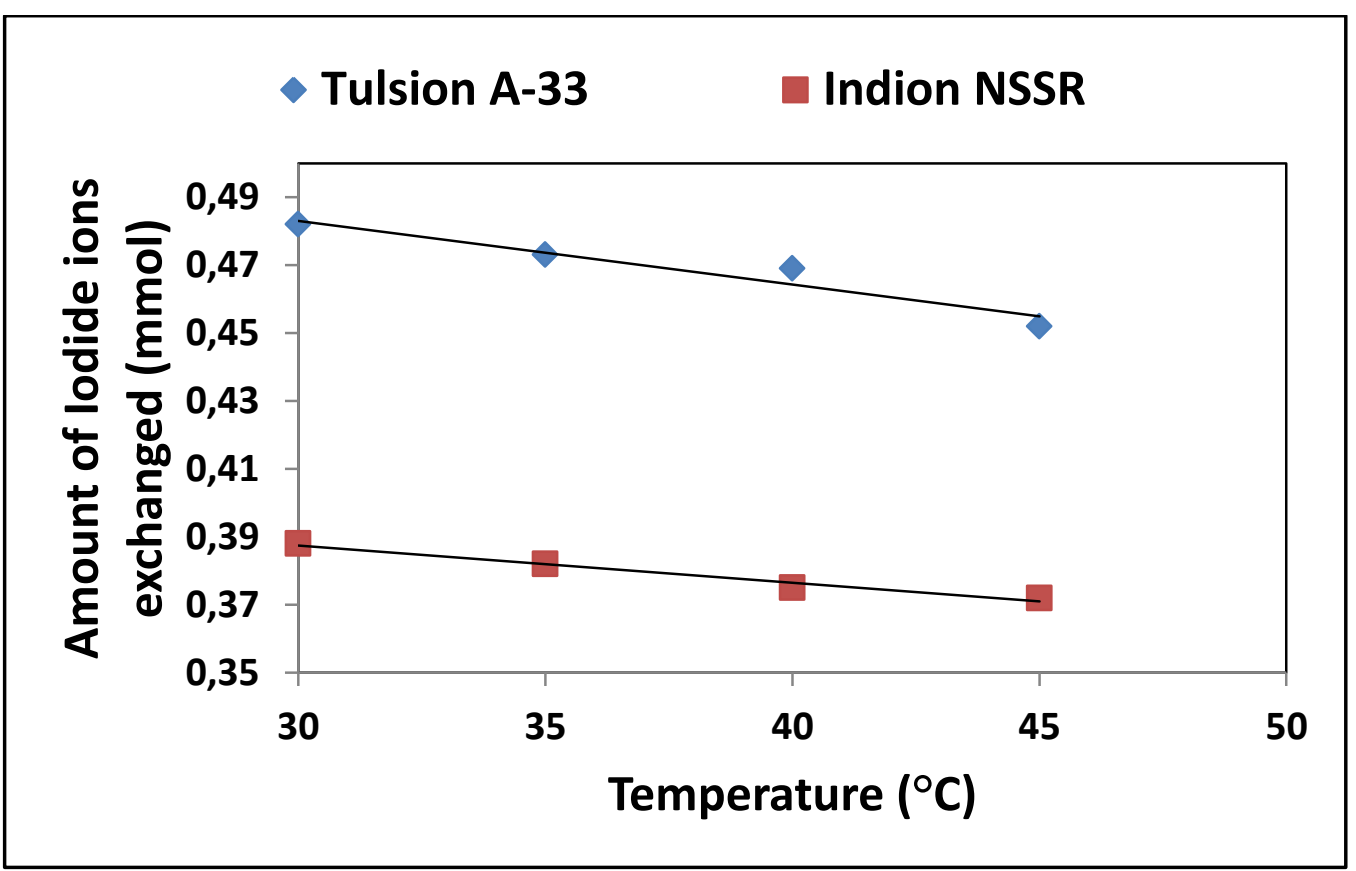

Figure 6. Correlation between Temperature of exchanging medium and amount of iodide ion exchanged.

Amount of ion exchange resin $=1.000 \mathrm{~g}$, Concentration of labeled exchangeable ionic solution $=0.003 \mathrm{M}$, Volume of labeled ionic solution $=250 \mathrm{~mL}$, Amount of exchangeable ions in $250 \mathrm{~mL}$ labeled solution $=0.750$ mmol, Correlation coefficient (r) for Tulsion A-33 = -0.9654, Correlation coefficient ( $r$ ) for Indion NSSR = 0.9886

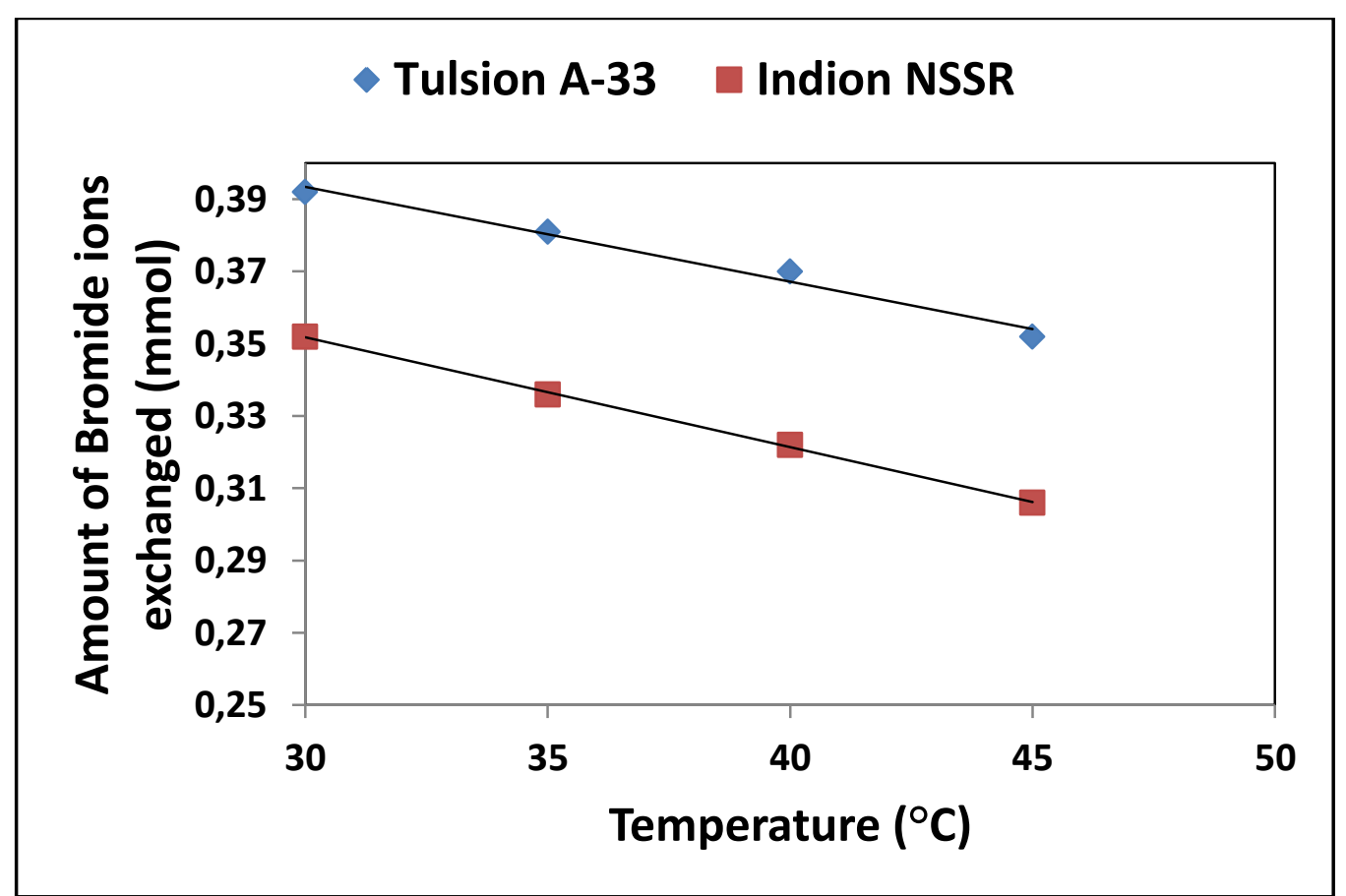

Figure 7. Correlation between Temperature of exchanging medium and amount of bromide ion exchanged.

Amount of ion exchange resin $=1.000 \mathrm{~g}$, Concentration of labeled exchangeable ionic solution $=0.003 \mathrm{M}$, Volume of labeled ionic solution $=250 \mathrm{~mL}$, Amount of exchangeable ions in $250 \mathrm{~mL}$ labeled solution $=0.750$ mmol +9 , Correlation coefficient (r) for Tulsion A-33 = -0.9915, Correlation coefficient (r) for Indion NSSR = - 


\section{RESULTS AND DISCUSSION}

\section{1. Comparative study of ion-isotopic exchange reactions}

In the present investigation it was observed that due to the rapid ion-isotopic exchange reaction taking place, the activity of solution decreases rapidly initially, then due to the slow exchange the activity of the solution decreases slowly and finally remains nearly constant. Preliminary studies show that the above exchange reactions are of first order [7-12]. Therefore logarithm of activity when plotted against time gives a composite curve in which the activity initially decreases sharply and thereafter very slowly giving nearly straight line (Figure 1), evidently rapid and slow ion-isotopic exchange reactions were occurring simultaneously [7-12]. Now the straight line was extrapolated back to zero time. The extrapolated portion represents the contribution of slow process to the total activity which now includes rapid process also. The activity due to slow process was subtracted from the total activity at various time intervals. The difference gives the activity due to rapid process only. From the activity exchanged due to rapid process at various time intervals, the specific reaction rates $(k)$ of rapid ion-isotopic exchange reaction were calculated. The amount of iodide / bromide ions exchanged $(\mathrm{mmol})$ on the resin were obtained from the initial and final activity of solution and the amount of exchangeable ions in $250 \mathrm{~mL}$ of solution. From the amount of ions exchanged on the resin $(\mathrm{mmol})$ and the specific reaction rates $\left(\mathrm{min}^{-1}\right)$, the initial rate of ion exchanged $(\mathrm{mmol} / \mathrm{min})$ was calculated.

Because of larger solvated size of bromide ions as compared to that of iodide ions, it was observed that the exchange of bromide ions occurs at slower rate than that of iodide ions. Hence under identical experimental conditions, the values of specific reaction rate $\left(\mathrm{min}^{-1}\right)$, amount of ion exchanged ( $\mathrm{mmol})$ and initial rate of ion exchange $(\mathrm{mmol} / \mathrm{min})$ are calculated to be lower for bromide ion-isotopic exchange reaction than that for iodide ion-isotopic exchange reaction as summarized in Tables 3 and 4. For both bromide and iodide ion-isotopic exchange reactions, under identical experimental conditions, while temperature remaining constant at $40.0{ }^{\circ} \mathrm{C}$, the values of specific reaction rate increases with increase in ionic concentration from $0.001 \mathrm{M}$ to $0.004 \mathrm{M}$ (Table 3). However, at constant ionic concentration of $0.003 \mathrm{M}$, the specific reaction rate was observed to decrease with rise in temperature from $30.0{ }^{\circ} \mathrm{C}$ to $45.0{ }^{\circ} \mathrm{C}$, (Table 4 ).

Thus in case of Tulsion A-33 at $40.0^{\circ} \mathrm{C}$ when the ionic concentration increases from $0.001 \mathrm{M}$ to $0.004 \mathrm{M}$, the specific reaction rate values for iodide ion-isotopic exchange increases from 0.208 to $0.240 \mathrm{~min}^{-1}$, while for bromide ion-isotopic exchange the values increases from 0.170 to $0.185 \mathrm{~min}^{-1}$. Similarly in case of Indion NSSR, under identical experimental conditions, the values for iodide ion-isotopic exchange increases from 0.143 to $0.179 \mathrm{~min}^{-1}$, while for bromide ion-isotopic exchange the values increases from 0.120 to $0.141 \mathrm{~min}^{-1}$. However when concentration of ionic solution was kept constant at $0.003 \mathrm{M}$ and temperature is raised from $30.0{ }^{\circ} \mathrm{C}$ to $45.0{ }^{\circ} \mathrm{C}$, in case of Tulsion A-33 the specific reaction rate values for iodide ion-isotopic exchange decreases from 0.250 to $0.218 \mathrm{~min}^{-1}$, while for bromide ion-isotopic exchange the values decreases from 0.187 to $0.173 \mathrm{~min}^{-1}$. Similarly in case of Indion NSSR, under identical experimental conditions, the specific reaction rate values for iodide ion-isotopic exchange decreases from 0.187 to $0.155 \mathrm{~min}^{-1}$, while for bromide ion-isotopic exchange the values decreases from 0.148 to $0.130 \mathrm{~min}^{-1}$. From the results, it appears that iodide ions exchange at the faster rate as compared to that of bromide ions which was related to the extent of solvation (Tables 3 and 4).

From the knowledge of $A_{i}, A_{f}$, volume of the exchangeable ionic solution $(V)$ and mass of ion exchange resin $(m)$, the $K_{d}$ value was calculated by the equation 


$$
K_{d}=\left[\left(A_{i}-A_{f}\right) / A_{f}\right] \times V / m
$$

Previous studies $[13,14]$ on halide ion distribution coefficient on strong and weak basic anion exchange resins indicate that the selectivity coefficient between halide ions increased at higher electrolyte concentrations. Adachi et al. [15] observed that the swelling pressure of the resin decreased at higher solute concentrations resulting in larger $\mathrm{K}_{\mathrm{d}}$ values. The temperature dependence of $\mathrm{K}_{\mathrm{d}}$ values on cation exchange resin was studied by Shuji et al. [16]; were they observed that the values of $K_{d}$ increased with fall in temperature. The present experimental results also indicates that the $K_{d}$ values for bromide and iodide ions increases with increase in concentration of the external ionic solution, however with rise in temperature the $\mathrm{K}_{\mathrm{d}}$ values were found to decrease. Thus in case of Tulsion A- 33 at $40.0^{\circ} \mathrm{C}$ when the ionic concentration increases from $0.001 \mathrm{M}$ to $0.004 \mathrm{M}$, the $\log \mathrm{K}_{\mathrm{d}}$ values for iodide ions increases from 8.4 to 11.2, while for bromide ions the values increases from 7.5 to 9.3. Similarly in case of Indion NSSR, under identical experimental conditions, the $\log \mathrm{K}_{\mathrm{d}}$ values for iodide ions increases from 6.5 to 8.0 , while for bromide ions the values increases from 3.1 to 4.8 . However when concentration of ionic solution was kept constant at $0.003 \mathrm{M}$ and temperature is raised from $30.0^{\circ} \mathrm{C}$ to $45.0^{\circ} \mathrm{C}$, in case of Tulsion A-33 the $\log \mathrm{Kd}$ values for iodide ions decreases from 11.6 to 10.0 , while for bromide ions the values decreases from 9.8 to 8.1 . Similarly in case of Indion NSSR, under identical experimental conditions, the $\log \mathrm{K}_{\mathrm{d}}$ values for iodide ions decreases from 8.8 to 7.1, while for bromide ions the values decreases from 5.5 to 3.9. It was also observed that the $\mathrm{K}_{\mathrm{d}}$ values for iodide ion-isotopic exchange reaction were calculated to be higher than that for bromide ion-isotopic exchange reaction (Tables 3 and 4).

3.2 Comparative study of anion exchange resins From the Table 3 and 4, it is observed that for iodide ion-isotopic exchange reaction by using Tulsion A-33 resin, the values of specific reaction rate $\left(\mathrm{min}^{-1}\right)$, amount of iodide ion exchanged (mmol), initial rate of iodide ion exchange $(\mathrm{mmol} / \mathrm{min})$ and $\log \mathrm{K}_{\mathrm{d}}$ were $0.229,0.469,0.107$ and 10.6 respectively, which was higher than $0.167,0.375,0.063$ and 7.6 respectively as that obtained by using Indion NSSR resins under identical experimental conditions of $40.0^{\circ} \mathrm{C}, 1.000 \mathrm{~g}$ of ion exchange resins and $0.003 \mathrm{M}$ labeled iodide ion solution. The identical trend was observed for the two resins during bromide ion-isotopic exchange reaction.

From Table 3, it is observed that at a constant temperature of $40.0^{\circ} \mathrm{C}$, as the concentration of labeled iodide ion solution increases $0.001 \mathrm{M}$ to $0.004 \mathrm{M}$, the percentage of iodide ions exchanged increases from $58.0 \%$ to $64.0 \%$ for Tulsion A-33 resins; and from $48.4 \%$ to $50.8 \%$ for Indion NSSR resins. Similarly in case of bromide ion-isotopic exchange reaction, the percentage of bromide ions exchanged increases from $45.6 \%$ to $50.4 \%$ for Tulsion A-33 resin; and from $39.8 \%$ to $44.6 \%$ for Indion NSSR resin. The effect of ionic concentration on percentage of ions exchanged is graphically represented in Figure 2.

From Table 4, it is observed that using Tulsion A-33 resins, for $0.003 \mathrm{M}$ labeled iodide ion solution, as the temperature increases $30.0^{\circ} \mathrm{C}$ to $45.0^{\circ} \mathrm{C}$, the percentage of iodide ions exchanged decreases from $64.3 \%$ to $60.3 \%$. While using Indion NSSR resins under identical experimental conditions the percentage of iodide ions exchanged decreases from $51.7 \%$ to $49.6 \%$. Similarly in case of bromide ion-isotopic exchange reaction, the percentage of bromide ions exchanged decreases from $52.3 \%$ to $46.9 \%$ using Tulsion A-33 resin, while for Indion NSSR resin it decreases from $46.9 \%$ to $40.8 \%$. The effect of temperature on percentage of ions exchanged is graphically represented in Figure 3.

The overall results indicate that under identical experimental conditions, as compared to Indion NSSR resins, Tulsion A-33 resins shows higher percentage of ions exchanged. Thus 
Tulsion A-33 resins show superior performance than Indion NSSR resins under identical operational parameters.

\section{3. Statistical Correlations}

The results of present investigation show a strong positive linear co-relationship between amount of ions exchanged and concentration of ionic solution (Figures 4, 5). In case of iodide ion-isotopic exchange reaction, the value of correlation coefficient $(r)$ was calculated as 0.9997 and 0.9999 respectively for Tulsion A-33 and Indion NSSR resins, while for bromide ion-isotopic exchange reaction, the respective values of $r$ calculated was 0.9999 and 0.9995 .

There also exist a strong negative co-relationship between amount of ions exchanged and temperature of exchanging medium (Figures 6,7). In case of iodide ion-isotopic exchange reactions the values of $r$ was calculated as

-0.9654 and -0.9886 respectively. Similarly in case of bromide ion-isotopic exchange reactions the respective values of $r$ calculated where -0.9915 and -0.9997 for both the resins.

\section{CONCLUSION}

The experimental work carried out in the present investigation will help to standardize the operational process parameters so as to improve the performance of selected nuclear grade ion exchange resins. The radioactive tracer technique used here can also be applied for characterization of different nuclear as well as non-nuclear grade ion exchange resins.

\section{Acknowledgement}

The author is thankful to Professor Dr. R.S. Lokhande (Retired) for his valuable help and support by providing the required facilities so as to carry out the experimental work in Radiochemistry Laboratory, Department of Chemistry, University of Mumbai, Vidyanagari, Mumbai -58.

\section{References}

[1] Radiotracer Applications in Industry- A Guidebook, Safety Reports Series No. 423, International Atomic Energy Agency (IAEA) VIENNA, June 2004.

[2] D. D. Sood, A. V. R. Reddy, N. Ramamoorthy, 'Applications of Radioisotopes In Physico-Chemical Investigations', in Fundamentals of Radiochemistry, Indian Association of Nuclear Chemists and Allied Scientists (IANCAS), pp. 253-263, January 2004.

[3] Clark M. W., Harrison J. J., Payne T. E., Journal of Colloid and Interface Science 356(2) (2011) 699-705.

[4] Dagadu C. P. K., Akaho E. H. K., Danso K. A., Stegowski Z., Furman L., Applied Radiation and Isotopes 70(1) (2012) 156-161.

[5] Koron N., Bratkic A., Ribeiro Guevara S., Vahcic M., Horvat M., Applied Radiation and Isotopes 70(1) (2012) 46-50. 
[6] Sood D. D., Proc. Int. Conf. on Applications of Radioisotopes and Radiation in Industrial Development, ed. Sood, D. D., Reddy, A. V. R., Iyer, S. R. K., Gangadharan, S. and Singh, G. (B.A.R.C., India) 35-53 (1998).

[7] Lokhande R. S., Singare P. U., Patil A. B., Radiochim. Acta 95(01) (2007) 111-114.

[8] Lokhande R. S., Singare P. U., Patil V. V., Radiochemistry 50(06) (2008) 638-641.

[9] Lokhande R. S., Singare P. U., Prabhavalkar T. S., Russ. J. Physical Chemistry A 82(9) (2008) 1589-1595.

[10] Lokhande R. S, Singare P. U., Tiwari S. R. D., Radiochemistry 50(06) (2008) 633-637.

[11] Singare P. U., Lokhande R. S., Ionics 18(4) (2012) 351-357.

[12] Lokhande R. S., Singare P. U., J. Porous Mater 15(03) (2008) 253-258.

[13] Heumann K. G., Baier K., Chromatographia 15(11) (1982) 701-703.

[14] Singare P. U., Lokhande R. S., Patil V. V., Prabhavalkar T. S., Tiwari S. R. D., European J. Chemistry 1(1) (2010) 47-49.

[15] Adachi S., Mizuno T., Matsuno R., J. Chromatogr. A 708 (1995) 177-183.

[16] Shuji A., Takcshi M., Ryuichi M., Biosci. Biotechnol. Biochem. 60(2) (1996) 338-340.

[17] Pravin U. Singare, International Letters of Chemistry, Physics and Astronomy 6 (2013) 1-5.

[18] P. U. Singare, International Letters of Chemistry, Physics and Astronomy 12 (2013) 1-13.

[19] P. U. Singare, International Letters of Chemistry, Physics and Astronomy 12 (2013) 14-27. 